\title{
PCR Regimen for Enhanced Specificity and Yield of Targeted Genomic DNA Sequences: ras and $\mathbf{p 5 3}$
}

\author{
Donald J. Phillips, Jane M. Benson, Janet M. Pruckler, and W. Craig Hooper
}

Hematologic Diseases Branch, Division of HIV/AIDS, National Center for Infectious Diseases, Centers for Disease Control, Public Health Service, U.S. Department of Health and Human Services, Atlanta, Georgia 30333

By weighting the PCR reaction in favor of specificity for the target sequence in the beginning cycles and for continued efficient amplification of the sequence into later cycles, we were able to show an improvement In the specificity and quantity of amplified ras and p53 sequences. Increased purity and yield of specific products favorably enhanced postPCR evaluation and interpretation of results using direct sequencing and single-stranded conformation polymorphism (SSCP) analysis when point mutations were present in DNA from tumor cell lines and tissues.
CR amplification of targeted genomic proto-oncogene and tumor suppressor gene DNA sequences from tumor tissues followed by allele-specific hybridization, ${ }^{(1-3)}$ RNase A mismatch cleavage ${ }^{(4)}$ direct sequencing, ${ }^{(5-8)}$ or singlestrand conformation polymorphism analysis $^{(9-11)}$ (SSCP) is increasingly used to detect and characterize specific activating or inactivating mutations in human cancer. For a review of these and other methods of mutation detection see Rossiter et al. ${ }^{(12)}$

However, we have found that the amplification of some selected ras and p53 sequences from genomic DNA is frequently accompanied by amplification of unwanted nonspecific DNA sequences of varying sizes that have the potential to interfere with the post-PCR product analysis. There is also the added disadvantage of specific products with low yields when unwanted amplifications occur. Other investigators have reported similar difficulties, especially in the amplification of ras DNA sequences. ${ }^{(5,8,11)}$ The propensity for ras sequence primers to amplify multiple sequences from genomic DNA may be related to the ras membership in a supergene family consisting of a large number of genes encoding the ras-related G-proteins ${ }^{(13)}$ and $\mathrm{H}$ and $\mathrm{K}$-ras pseudogenes. ${ }^{(14)}$

The location of primers in intron sequences has been used to diminish unwanted amplification; however, this is sometimes difficult, especially when post-PCR SSCP analysis is the objective, because the detection of single-base substitutions as mobility shifts is greatest when the DNA fragment size is $\leqslant 200$ $\mathrm{bp}^{(10)}$ and large fragments would entail additional treatment such as endonuclease digestion. ${ }^{(15)}$ In addition, intron sequence polymorphisms would also be detected. Saiki et al. ${ }^{(16)}$ first noted the importance of selective priming in the first few cycles of the PCR to preclude the accumulation of unwanted product(s). Ruano et al. ${ }^{(17,18)}$ recognized the dual nature of the PCR reaction and described a biphasic protocol (booster PCR) for screening and amplification of low copy template that provided an advantage in the amplification of target, although there was a loss of specificity with increasingly dilute samples. The advantage in amplification efficiency of specific product was attained primarily from a stoichiometric adjustment to primer/template ratios to minimize the occurrence of primer artifacts, especially primer-dimer, which was mostly responsible for diminished yield of specific product in the conventional PCR. The utility of the booster PCR protocol was demonstrated in the amplification of single DNA molecules for studying the haplotype of multiple polymorphisms. ${ }^{(19)}$ The incorporation of a higher than expected annealing temperature $^{(20)}$ or touchdown PCR has been employed to improve specificity. This approach was used to circumvent spurious priming and primer artifacts during amplification of low template copy without lengthy optimization procedures. However, a 250-bp nonspecific product was reported, presumably arising from a 14/20-bp 3' amplimer partial match to template. ${ }^{(20)}$ Preheating of $\mathrm{PCR}$ reactants, ${ }^{(21)}$ (hot-start) to $70^{\circ} \mathrm{C}$ followed by the addition of a final critical component was used to launch the PCR into the 
first cycle from a pristine state, i.e., without preamplification artifacts, which can arise during the first ascending temperature. Similar stringency control of primer annealing but throughout the cycling process has been reported when formamide was incorporated in the reaction mixture. ${ }^{(22)}$ The importance of approaching the first few cycles of PCR as a screening phase and strategies to single out with high stringency a particular target sequence, which is then as the preferred template preferentially amplified in the ensuing cycles with a boosted complement of reactants, was discussed in a recent commentary by Ruano et al. ${ }^{(23)}$

To improve the specificity and yield of the amplified product, the dynamics of the PCR reaction was thus modified by incorporation of the booster PCR concept of Ruano et al. ${ }^{(17,18,23)}$ so that the target sequence was selectively replicated in a stringent screening phase prior to the exponential amplification characteristic of early PCR cycles. We now describe those modifications that have enabled us to generate PCR-amplified ras and p53 gene fragments with high yields, predictable specificity, and precision. These modifications may have a general utility in the amplification of genomic or other DNA sequences.

\section{METHODS}

\section{Synthetic Oligodeoxyribonucleotide Primers}

Primers were selected based on previously published data ${ }^{(2,24)}$ and with the aid of a commercial computer program (Oligo 3.4, National Biosciences, Hamel, $\mathrm{MN}$ ) that was used to select 20-mer sense and antisense amplimer sequences with minimum secondary structure, dimer formation, and compatible $T_{\mathrm{m}}$ values (Table 1). Oligodeoxyribonucleotides were synthesized on a solid support-controlled pore glass (CPG) resin using an automated DNA synthesizer (Applied Biosystems Model 381A, Foster City, CA) and the beta cyanoethyl phosphoramidite chemical synthesis method. Oligodeoxyribonucleotides were cleaved from the CPG and deprotected using the standard ammonium hydroxide treatment at $55^{\circ} \mathrm{C}$ and then desalted ${ }^{(25)}$ using 10DG columns (Bio-Rad, Richmond, CA) as described previously.

TABLE 1 Oligodeoxyribonucleotide Primer Sequences Used in the PCR

\begin{tabular}{|c|c|c|c|c|c|}
\hline & Gene & Exon & Sense & Anti-sense & $\mathrm{bp}$ \\
\hline & & & $5^{\prime} \longrightarrow 3^{\prime}$ & $5^{\prime} \longrightarrow 3^{\prime}$ & \\
\hline 1. & $\mathrm{H}-\mathrm{ras}$ & 1 & GACGGAATATAAGCTGGTGG & GGGTCGTATTCGTCCACAAA & 99 \\
\hline 2 . & $\mathrm{K}$-ras & 1 & GACTGAATATAAACTTGTGG & CTATTGTTGGATCATATTCG & 107 \\
\hline 3. & $\mathrm{~N}$-ras & 1 & GACTGAGTACAAACTGGTGG & CTCTATGGTGGGATCATATT & 109 \\
\hline 4 . & H-ras & 2 & AAGCAGGTGGTCATTGATGG & CGCATGTACTGGTCCCGCAT & 95 \\
\hline 5 . & $\mathrm{K}-\mathrm{ras}$ & 2 & TTCCTACAGGAAGCAAGTAG & AGAAAGCCCTCCCCAGTCCT & 123 \\
\hline 6 . & $N-r a s$ & 2 & GGTGAAACCTGTTTGTTGGA & ATACACAGAGGAAGCCTTCG & 103 \\
\hline 7. & p53 & 5 & TGTTCACTTGTGCCCTGACT & CAGCCCTGTCGTCTCTCCAG & 268 \\
\hline 8 . & p53 & 6 & TGGTTGCCCAGGGTCCCCAG & GGAGGGCCACTGACAACCA & 223 \\
\hline 9 . & p53 & 7 & CTTGCCACAGGTCTCCCCAA & AGGGGTCAGCGGCAAGCAGA & 237 \\
\hline 10 . & p53 & $8 \& 9$ & TTGGGAGTACATGGAGCCT & AGTGTTAGACTGGAAACTTT & 445 \\
\hline
\end{tabular}

\section{Isolation of Genomic DNA}

We used the Applied Biosystems (Foster City, CA) Nucleic Acid Extractor model $340 \mathrm{~A}$ to isolate sample DNA from human tumor cell lines (ATCC, Rockville, MD) and human primary tumor tissue specimens. Following cell lysis in $4 \mathrm{~m}$ urea and $1 \% N$-laurylsarcosine, nuclei were digested in proteinase $\mathrm{K}$, extracted with phenol/chloroform, and precipitated with ethanol. DNAs were rehydrated from the filter membranes by storage in water at $4^{\circ} \mathrm{C}$ for $48-60 \mathrm{hr}$. Sample DNA concentration was determined by optical density measurement at $260 \mathrm{~nm}$ using an extinction coefficient of $E^{1 \% 1 \mathrm{~cm}}$ $=200.0$. Human placental DNA was purchased from Oncor (Gaithersburg, MD).

\section{Polymerase Chain Reaction}

The PCR procedure for in vitro amplification of template DNA has been previously described in detail..$^{(26,27)}$ The conventional PCR methodology used here employed kit reactants for amplification of template DNAs, as suggested by the manufacturer (Perkin-Elmer Cetus, Norwalk, CT), which were combined in thinwalled Gene Amp reaction tubes in the following order in water to give a $\mathrm{pH} 8.3$ final volume of $100 \mu \mathrm{l}$ and final concentrations of: $10 \mathrm{~mm}$ Tris- $\mathrm{HCl}, 50 \mathrm{mM} \mathrm{KCl}$, $1.5 \mathrm{mM} \mathrm{MgCl}_{2}, 0.01 \%$ gelatin, $200 \mu \mathrm{M}$ of each dNTP, $0.50 \mu \mathrm{M}$ (50 pmoles) of each primer, and $1 \mu \mathrm{g}$ genomic DNA. The charged tubes were then heated to $95^{\circ} \mathrm{C}$ in a heat block for $5 \mathrm{~min}$ to denature genomic DNA. Following this, 2.5 units of Taq DNA polymerase were added to the tube contents, which were then briefly vortexed, centrifuged, and overlaid with $\sim 30 \mu \mathrm{l}$ of mineral oil and placed in a thermal cycler (Perkin-Elmer Cetus, Norwalk, CT). An amplification cycle consisted of the following three segments: $95^{\circ} \mathrm{C}, 1 \mathrm{~min} ; 55^{\circ} \mathrm{C}, 1 \mathrm{~min}$; $72^{\circ} \mathrm{C}, 1.5 \mathrm{~min}$ for denaturation, annealing, and extension, respectively. The PCR product was generally evaluated after 35 cycles of amplification. However, as indicated in the text, amplification was extended to 45 cycles in some instances, and an aliquot of $10 \mu \mathrm{l}$ was removed at the end of the $72^{\circ} \mathrm{C}$ segment of cycles $30,35,40$, and 45 for later evaluation and comparison with the following modified PCR protocol.

In the modified PCR reaction, $1 \mu \mathrm{g}$ of template DNA was first replicated in a $50-\mu l$ reaction mixture containing final concentrations of $10 \mathrm{mM}$ Tris- $\mathrm{HCl}, 50$ $\mathrm{mM} \mathrm{KCl}, 0.01 \%$ gelatin, $0.55 \mathrm{mM} \mathrm{MgCl}_{2}$, $50 \mu \mathrm{M}$ of each dNTP, $2.5 \%$ formamide, and $0.1 \mu \mathrm{M}$ ( 5 pmoles) of each primer. Template was premelted as above, 1.25 units of Taq polymerase was added and was followed by 14 cycles of replication, with each cycle consisting of a DNA denaturation $\left(95^{\circ} \mathrm{C}, 30 \mathrm{sec}\right)$ and combined primer annealing and extension segment $\left(55^{\circ} \mathrm{C}, 30 \mathrm{sec}\right)$. Following this phase, $50 \mu \mathrm{l}$ of $\mathrm{H}_{2} \mathrm{O}$ containing fresh PCR reactants at concentrations of 10 $\mathrm{mM}$ Tris- $\mathrm{HCl}, 50 \mathrm{mM} \mathrm{KCl}, 0.01 \%$ gelatin, $2.35 \mathrm{mM} \mathrm{MgCl} 2,150 \mu \mathrm{M}$ of each dNTP, $2.5 \%$ formamide, $0.5 \mu \mathrm{M}$ (50 pmoles) of each primer, and 2.5 units of Taq polymerase were directly added with mixing to the contents of the tubes having just completed 14 cycles of amplification. Thermal cycling was resumed for an additional 31 cycles, including an extension segment of $72^{\circ} \mathrm{C}$ for $45 \mathrm{sec}$ in each cycle. Where indicated, a $10-\mu$ l sample aliquot was removed for evaluation after $30,35,40$, and 45 cycles of amplification. 


\section{Single-strand Conformation Polymorphism Analysis}

The PCR protocols for amplification of genomic DNA sequences for SSCP analysis were used as described above except that the final reaction volume was proportionately reduced to $10 \mu \mathrm{l}$. One microliter of $\left[\alpha-{ }^{32} \mathrm{P}\right] \mathrm{dCTP}(3000 \mathrm{Ci} / \mathrm{mmole}$, NEN) was incorporated into the second phase of the modified PCR reaction mixture to effect internal labeling of the amplified DNA fragments. PCR products were diluted $1 / 20$ in $95 \%$ formamide containing $20 \mathrm{~mm}$ EDTA, $0.05 \%$ bromophenol blue, $0.05 \%$ zylene cyanol, heated to $90^{\circ} \mathrm{C}$ for $3 \mathrm{~min}$ and placed on wet ice 3-5 $\mathrm{min}$ before loading $1 \mu \mathrm{l}$ of sample/lane. Gel electrophoresis conditions were $4^{\circ} \mathrm{C}$ and 40 watts constant power for 4-6 hr as described previously. ${ }^{(10)}$

\section{RESULTS AND DISCUSSION}

Selection of $\operatorname{ras}^{(2)}$ and $\mathrm{p} 53^{(24)}$ primer pairs (Table 1) for PCR amplification of target DNA sequences was based on previously published data and computer analysis. Following synthesis, the primers were evaluated empirically for their ability to amplify sequences of exons 1 and 2 of the c-H-ras- $1, \mathrm{c}-\mathrm{K}-$ ras-2, and $\mathrm{N}$-ras genes and exons $5,6,7,8$, and 9 with intervening sequence of the p53 gene using placental DNA as template and conventional PCR methodology as described in the Methods section. Basesubstituted activating mutations in known critical codons in exons 1 and 2 of the ras proto-oncogenes and exons 5-9 loss-of-function mutations of the p53 tumor suppressor gene are the most commonly encountered mutations in human cancer. The PCR amplification of these sequences generally produced DNA fragments of the expected size with a given pair of primers. However, poor yields accompanied by smears and/or unwanted PCR products observed as inappropriately sized bands were often present in agarose and/or polyacrylamide gels following electrophoresis and ethidium bromide staining as typically seen in Figures $1 \mathrm{~A}$ and 2.

To target selectively genomic sequences difficult to amplify in conventional PCR, we attempted to change the dynamics of the PCR early cycles with a booster $\mathrm{PCR}^{(17,18,23)}$ protocol in which the target sequence is selectively repli-

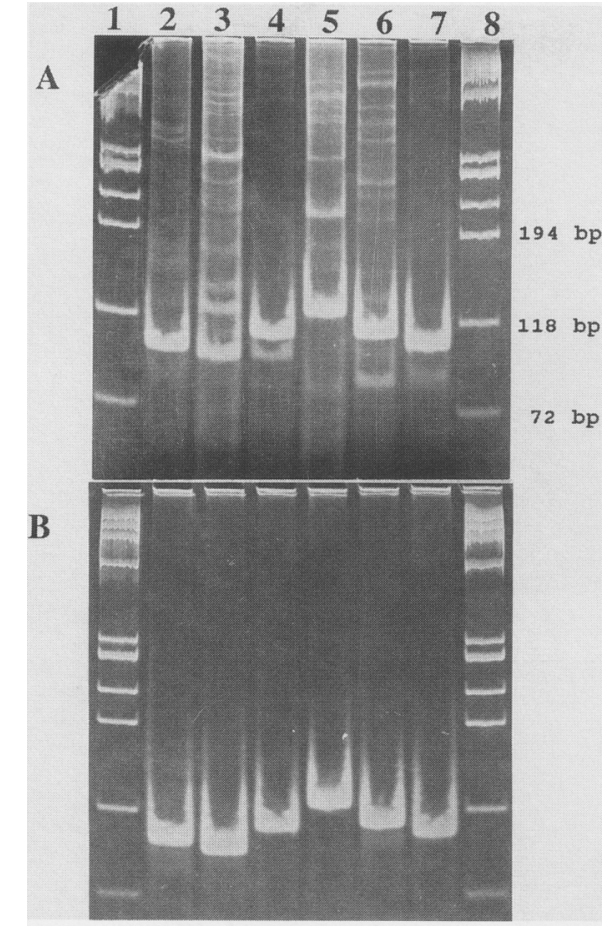

FICURE 1 Photograph of ethidium bromidestained polyacrylamide electrophoresis gels showing amplified DNA fragments from exons 1 and 2 of the $\mathrm{H}-, \mathrm{K}-$, and $\mathrm{N}$-ras sequences, respectively (lanes $2-7$ ). $A$ and $B$ contrast the result attained using conventional and modified PCR methodology, respectively. The gels were deliberately overloaded with large sample volumes $(100 \mu \mathrm{l})$ to show unequivocally the differences in amplification of product by the two protocols. Outside lanes contain a HaeIII digest of $\phi \mathrm{X} 174 \mathrm{DNA}$ as size marker.

cated in an initial screening phase by minimizing the probability of mispriming. First, the annealing of primers to premelted template and extension of DNA were limited to a single 30-sec segment because Taq DNA polymerase is reportedly able to incorporate 24 nucleotides $/ \mathrm{sec} \cdot$ molecule at $55^{\circ} \mathrm{C}^{(28)}$ a commonly employed annealing temperature for 20-mer sequences with $50 \%$ G:C, 50\% A:T. Second, molar amounts of dNTPs and primers were reduced sequentially to approximate minimal essential concentrations for product development, and formamide ${ }^{(22)}$ was incorporated to increase the stringency of primer annealing. Third, to amplify stringently replicated template exponentially, we spiked the reaction mixture by the addition of new reactants, as described in the Methods section. Thermal cycling was continued for another $31 \mathrm{cy}$ cles, and a cycle segment was incorporated for extension at $72^{\circ} \mathrm{C}$ for $45 \mathrm{sec}$ to permit the polymerase more time to extend the increasing amounts of primed specific target fragments.

Figure 1, A and B, shows ras gene DNA sequences following electrophoresis in a polyacrylamide gel and ethidium bromide staining after 35 and 45 cycles of amplification in the conventional and modified PCR regimens, respectively. To show explicitly the difference in products amplified from the two protocols, the gels were overloaded with sample, resulting in dense trailing bands. In addition, excessive cycling (35) was generally used to maximize product yield in the conventional PCR for later gel purification and direct sequencing. Lanes 2 and 3 contain the amplified H-ras- 1 exons 1 and 2 fragments, respectively. Similarly, c-K-ras-2 exons 1 and 2 fragments

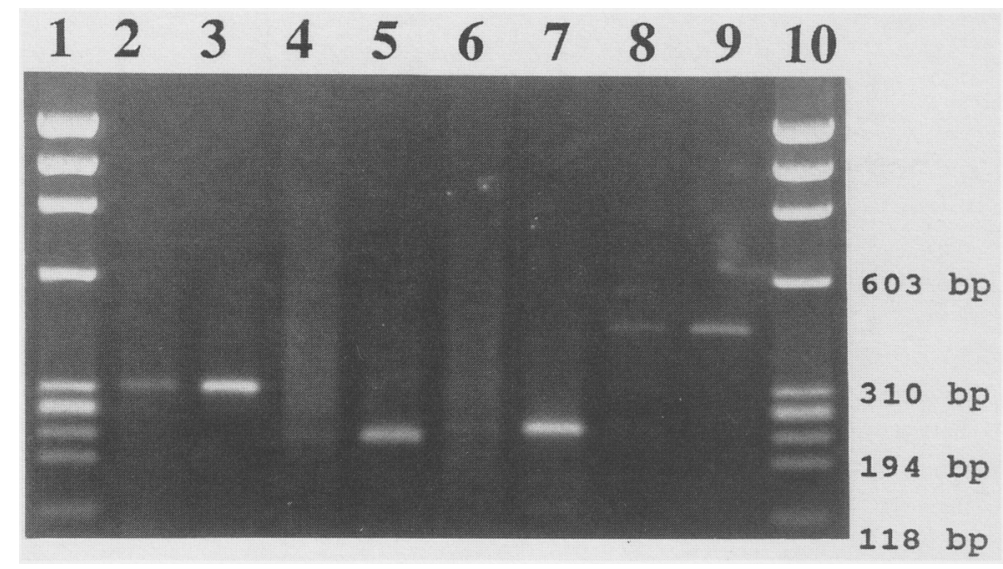

FIGURE 2 Photograph of ethidium bromide-stained 1\% agarose electrophoresis gel showing p53 PCR-amplified DNA fragments. Lanes 2 and 3 show the p53 exon 5 amplified in conventional and modified PCR, respectively, and similarly, exon 6 in lanes 4 and 5, exon 7 in lanes 6 and 7, and exons 8-9 with intervening sequence in lanes 8 and 9 . 


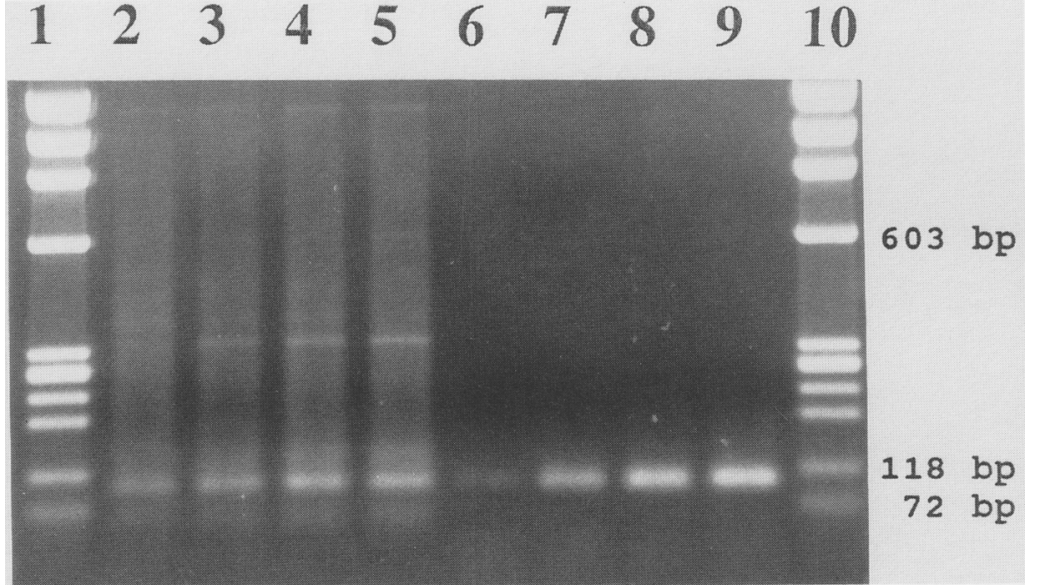

FIGURE 3 Agarose (1\%) gel analysis of $\mathrm{H}$-ras exon 2 PCR products after 30, 35, 40, and 45 cycles of amplification in the conventional PCR (lanes $2-5$, respectively) (10 $\mu \mathrm{l}$ sample volume). Similarly, lanes 6-9 show the H-ras exon 2 amplified product using the modified PCR procedure. (Lanes 1 and 10) HaeIII $\phi X 174$ digest marker.

are in lanes 4 and 5 and $\mathrm{N}$-ras exons 1 and 2 fragments in lanes 6 and 7. In Figure $1 \mathrm{~B}$, using the modified PCR regimen, only one band of the expected size, based on previously published ras gene sequences available through the Genetics Computer Group, ${ }^{(29)}$ was detected and confirmed by direct sequencing (data not shown). Outside lanes of Figure 1 , as in other figures, contain a HaeIII digest of $\phi X 174$ DNA for size reference. Figure 2 is a photograph of an agarose electrophoresis gel comparing in adjacent lanes p53 exons 5-9 DNA fragments after amplification using conventional and modified PCR methodology, respectively. The presence of nonspecific product is indicated by smearing due to spurious amplification, probably of a linear nature, and is most notable in lanes 4 and 6 . Note especially the reduction in discernible smearing and the increased amounts of specific products elicited in the modified or booster PCR protocol (lanes 3, 5, 7, and 9). Figure 3 shows an agarose electrophoresis gel of the $\mathrm{H}$-ras- 1 exon 2 fragment after $30,35,40$, and 45 cycles of amplification in lanes $2-5$, respectively, using conventional PCR methodology and similarly lanes 6-9 using the modified PCR. Visual examination of ethidium bromide-stained product intensities reveals that in the conventional PCR, unwanted product is seen after the 30th cycle and that the amount of specific product present after 45 cycles is marginally, if at all, different from that present after 35 cycles of amplification. Loss of amplification effi- ciency in the early cycles as a result of reduced molar concentrations of reactants and increased stringency deliberately established in the modified PCR is apparent when band intensities from the two methods are compared after $30 \mathrm{cy}$. cles of amplification (lanes 2 versus 6 ). However, nonspecific bands that are present after 30 cycles in the conventional PCR remain undetectable after a total of 45 cycles in the modified PCR, and the yield of product is seen to inties of wild-type DNAs. crease through 45 cycles of amplification (cf. lanes 6-9). We did not extend the amplification beyond 45 cycles in the modified PCR, although it would have been of interest to determine the point at which the target sequence product saturates and when nonspecific product would eventually appear.

Analysis of amplified DNA fragments for SSCPs following conventional PCR amplification of the six ras and four p53 sequences was sometimes obfuscated with multiple single-strands of DNA making interpretation difficult or, as in the case of p53, a failed PCR altogether. However, following PCR amplification using the described modifications, DNA analysis for SSCPs has generally shown improved, readily interpretable autoradiographs typically seen as in Figure 4. Shown are the electrophoretically separated complementary single-strand DNA amplified fragments of exon 6 (panel A) and exon 7 (panel B) of the p53 gene from 14 samples and a no DNA control (lane 15). Lane 3 , also a negative control, contains HL60 cell line DNA from which most of the p53 gene is deleted. With SSCP analysis, base substitution mutations are detected as mobility shifts in one or both complementary singlestrand DNA fragments (bands) relative to that of a reference sequence (lane 1$)$. The HUT78 cell line DNA in panel A, lane 5,

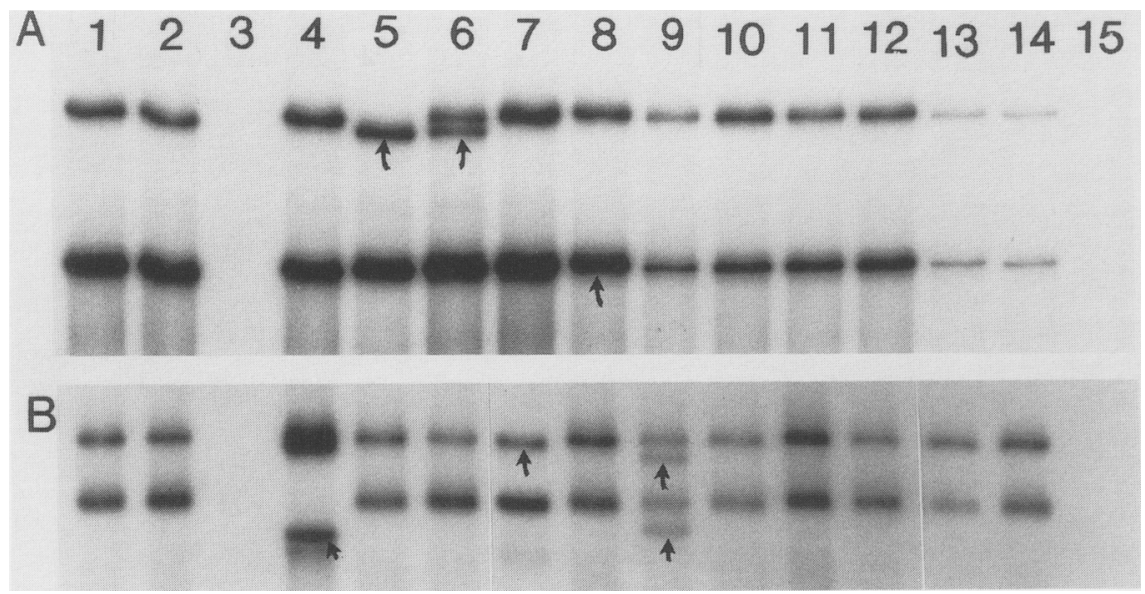

FIGURE 4 Autoradiograph from nondenaturing polyacrylamide gel electrophoresis showing a SSCP analysis of p53 DNA fragments amplified using the modified PCR procedure. (Lanes 2-8) Tumor cell line DNAs; (lanes 9-14) primary tumor tissue DNAs; (lane 1) placental DNA; (lane 15) a no DNA control. The sample in lane 3 is the promyelocytic HL60 cell line DNA deficient for most of the p53 gene. (A) Amplified exon 6. SSCPs are indicated by $\rightarrow$ in the HUT78, Jurkat, and U138 cell line DNA, lanes 5,6 , and 8 , respectively. Similarly, in $B$, exon 7 SSCPs are indicated in HS683 and RD tumor cell lines and a neuroblastoma DNA in lanes 4, 7, and 9, respectively. Unmarked complementary single-stranded conformers in remaining lanes characterize mobili- 
shows a mobility shift of one singlestrand, and the absence of a normal allele here was confirmed by direct sequencing (data not shown) in which a C:T transition in the first nucleotide of codon 196 (CGA $\rightarrow$ TGA) was determined. Jurkat cell line DNA, also in this panel, lane 6 , shows the presence of normal alleles along with a third band. The presence of normal and mutated alleles was confirmed by direct sequencing (codon 196, CGA $\rightarrow$ CGA/TGA). With cell line U138 DNA, lane 8, a less conspicuous mobility shift was detected and sequenced to reveal a codon 213, $\mathrm{CGA} \rightarrow \mathrm{CGA} / \mathrm{AGA}$ mutation. In panel $\mathrm{B}$, cell line HS683 DNA, lane 4, demonstrates a mobility shift with loss of normal allele which was sequenced revealing a codon $248, C G G \rightarrow C A G$ second nucleotide transition. Lane 7 contains an $\mathrm{RD}$ cell line DNA in which a very subtle mobility shift was noted and determined to have a codon 248 , CGG $\rightarrow$ TGG firstbase transition mutation. The loss of normal alleles generally cannot be demonstrated in SSCP analysis of primary tumor tissue because of the presence of normal cells, ${ }^{(11)}$ which is typified in lane 9 of panel B with a DNA from a neuroblastoma surgical specimen. A splice donor consensus sequence G:T transversion $\left(5^{\prime}\right.$-GTGAG $\rightarrow$ GT/TTGAG-3') was determined in this specimen.

These observations support the conclusion that specificity, while accompanied by some loss of amplification efficiency, is attained in the early cycles of PCR under conditions of reduced molar concentrations of reactants and increased stringency and that amplification efficiency is extended into later cycles with the addition of fresh reactants without eliciting unwanted products after 45 cycles of amplification. These observations also provide experimental proof of the value of booster PCR ${ }^{(17,18,23)}$ in the amplification of DNA fragments from several loci of the human genome.

\section{ACKNOWLEDGMENT}

We thank David Swan for constructive comments on the manuscript. Use of tradenames is for identification only and does not imply endorsement by the Public Health or by the U.S. Department of Health and Human Services.

\section{REFERENCES}

1. Bos, J.L., M. Verlaan-de Vries, A.M. Jan- sen, G.H. Veeneman, J.H. van Boom, and A.J. van der Eb. 1984. Three different mutations in codon 61 of the human N-ras gene detected by synthetic oligonucleotide hybridization. Nucleic Acids Res. 12: 9155-9162.

2. Verlaan-de Vries, M., M.E. Bogaard, H. van den Elst, J.H. van Boom, A. van der Eb, and J.L. Bos. 1986. A dot-blot screening procedure for mutated ras oncogenes using synthetic oligodeoxynucleotides. Gene 50: 313-320.

3. Vogelstein, B., E.R. Fearon, S.R. Hamilton, S.E. Kern, A.C. Preisinger, M. Leppert, Y. Nakamura, R. Whyte, A.M.M Smits, and J.L. Bos. 1988. Genetic alterations during colorectal tumor development. N. Engl. J. Med. 319: 525-532.

4. Myers, R.M., Z. Larin, and T. Maniatis. 1985. Detection of single base substitutions by ribonuclease cleavage at mismatches in RNA:DNA duplexes. Science 230: 1242-1246.

5. Collins, S.J. 1988. Direct sequencing of amplified genomic fragments documents $\mathrm{N}$-ras point mutations in myeloid leukemia. Oncogene Res. 3: 117-123.

6. Cadavid, N.F.G., D. Zhou, H. Battifora, M. Bar-Eli, and M.J. Cline. 1989. Direct sequencing analysis of exon 1 of the c-K-ras gene shows a low frequency of mutations in human pancreatic adenocarcinomas. Oncogene 4: 1137-1140.

7. Radich, J.P., C.L. Kopecky, C.L. Willman, J. Weick, D. Head, F. Appelbaum, and S.J. Collins. 1990. N-ras mutations in adult de novo acute myelogenous leukemia: Prevalence and clinical significance. Blood 76: 801-807.

8. Tada, M., M. Omata, and M. Ohto. 1990. Analysis of ras gene mutations in human hepatic malignant tumors by polymerase chain reaction and direct sequencing. Cancer Res. 50: 1121-1124.

9. Hensel, C.H., R.H. Xiang, A.Y. Sakaguchi, and S.L. Naylor. 1989. Use of the single strand conformation polymorphism technique and PCR to detect p53 gene mutations in small cell lung cancer. Cancer Res. 49: 5530-5533.

10. Orita, M., Y. Suzuki, T. Sekiya, and K. Hayashi. 1989. Rapid and sensitive detection of point mutations and DNA polymorphism using the polymerase chain reaction. Genomics 5: 874-879.

11. Suzuki, Y., M. Orita, M. Shiraishi, K. Hayashi, and T. Sekiya. 1990. Detection of ras gene mutations in human lung cancers by single-strand conformation polymorphism analysis of polymerase chain reaction products. Oncogene 5: 1037-1043.

12. Rossiter, B.J.F. and C.T. Caskey. 1990. Molecular scanning methods of mutation detection. J. Biol. Chem. 265: 12753-12756.

13. Hall, A. 1990. The cellular functions of small GTP-binding proteins. Science 249: 635-640.
14. Barbacid, M. 1987. ras genes. Annu. Rev. Biochem. 56: 779-827.

15. Iwahana, H., K. Yoshimoto, and $M$. Itakura. 1992. Detection of point mutations by SSCP of PCR-amplified DNA after endonuclease digestion. BioTechniques 12: 64-66.

16. Saiki, R.K., D.H. Gelfand, S. Stoffel, S.J. Scharf, R. Higuchi, G.T. Horn, K.B. Mullis, and H.A. Erlich. 1988. Primer-directed enzymatic amplification of DNA with a thermostable DNA polymerase. Science 239: 487-494.

17. Ruano, G., W. Fenton, and K.K. Kidd. 1989. Biphasic amplification of very dilute DNA samples via "booster" PCR. Nucleic Acids Res. 17: 5407.

18. Ruano, G. and K.K. Kidd. 1989. Booster PCR: A biphasic paradigm for amplification of a few molecules of target. In $\mathrm{Am}$ plifications - A forum for PCR users, issue 3 , pp. 12-13. Perkin-Elmer Cetus, Norwalk, CT.

19. Ruano, G., K.K. Kidd, and J.C. Stephens. 1990. Haplotype of multiple polymorphisms resolved by enzymatic amplification of single DNA molecules. Proc. Natl. Acad. Sci. 87: 6296-6300.

20. Don, R.H., P.T. Cox, B.J. Wainwright, K. Baker, and J.S. Mattick. 1991. "Touchdown" PCR to circumvent spurious priming during gene amplification. Nucleic Acids Res. 19: 3749.

21. D'Aquila, R.T., L.J. Bechtel, J.A. Videler, J.J. Eron, P. Gorczyca, and J.C. Kaplan. 1991. Maximizing sensitivity and specificity of PCR by preamplification heating. Nucleic Acids Res. 19: 3749.

22. Sarkar, G., S. Kapelner, and S.S. Sommer. 1990. Formamide dramatically improves the specificity of PCR. Nucleic Acids Res. 18: 7465 .

23. Ruano, G.D.E. Brash, and K.K. Kidd. 1991. PCR: The first few cycles. In Amplifications -A forum for PCR users, issue 7, pp. 1-4. Perkin-Elmer Cetus, Norwalk, CT.

24. Lehman, T.A., W.P. Bennett, R.A. Metcalf, J.A. Welsh, J. Ecker, R.V. Modali, S. Ullrich, J.W. Romano, E. Appella, J.R. Testa, B.I. Gerwin, and C.C. Harris. 1991. p53 mutations, ras mutations, and p53-heat shock 70 protein complexes in human lung carcinoma cell lines. Cancer Res. 51: 4090-4096.

25. Fisher, I., S. Magil, and M. Kopczynski. 1990. A rapid and inexpensive procedure for desalting synthetic oligonucleotides. BioTechniques 9: 300-301.

26. Saiki, R.K., S. Scharf, F. Faloona, K.B. Mullis, G.T. Horn, H.A. Erlich, and N. Arnheim. 1985. Enzymatic amplification of $\beta$-globin genomic sequences and restriction site analysis for diagnosis of sickle cell anemia. Science 230: 1350-1354.

27. Mullis, K.B. and F.A. Faloona. 1987. Specific synthesis of DNA in vitro via a poly- 
merase catalyzed chain reaction. Methods Enzymol. 155: 335-350.

28. Innis, M.A., K.B. Myambo, D.H. Gelfand, and M.A.D. Brow. 1988. DNA sequencing with Thermus aquaticus DNA polymerase. Proc. Natl. Acad. Sci. 85: 9436-9440.

29. Devereus, J., P. Haeberli, and O. Smithier. 1984. A comprehensive set of sequence analysis programs for the VAX. Nucleic Acids Res. 12: 384-395.

Received March 23, 1992; accepted in revised form June 8, 1992. 


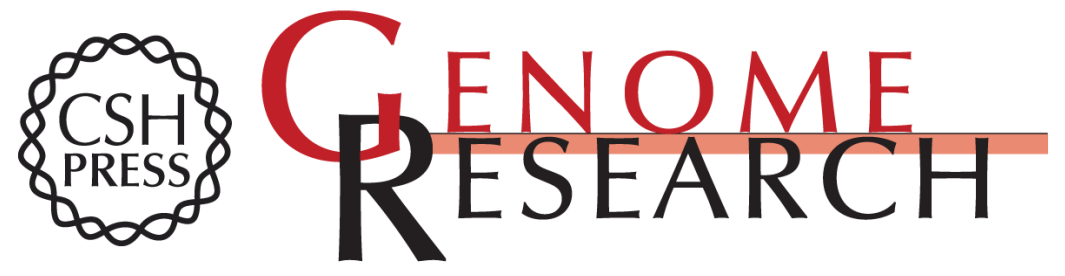

\section{PCR regimen for enhanced specificity and yield of targeted genomic DNA sequences: ras and $\mathrm{p} 53$.}

D J Phillips, J M Benson, J M Pruckler, et al.

Genome Res. 1992 2: 45-50

Access the most recent version at doi:10.1101/gr.2.1.45

References This article cites 27 articles, 11 of which can be accessed free at:

http://genome.cshlp.org/content/2/1/45.full.html\#ref-list-1

\section{License}

Email Alerting Receive free email alerts when new articles cite this article - sign up in the box at the Service top right corner of the article or click here.

\section{Affordable, Accurate Sequencing.}

To subscribe to Genome Research go to: https://genome.cshlp.org/subscriptions 